\title{
Farklı Anestezik Ajanların Rejyonel İntravenöz Anestezi Yapılan Hastalarda Elektrokardiyografik Değişiklikler Üzerine Etkisi
}

\section{Effect of Different Anesthetic Agents Management on Electrocardiographic Changes of Patients Operated under Regional Intravenous Anesthesia}

\author{
${ }^{1}$ İlknur Suidiye YORULMAZ, ${ }^{2}$ Gökçe AKMAN KÖSE, ${ }^{3}$ Yavuz DEMIRARAN, ${ }^{4}$ Şengül CANGÜR \\ ${ }^{1}$ Department of Anesthesiology and Intensive Care, Düzce University, Faculty of Medicine, Duzce, Turkey \\ ${ }^{2}$ Department of Anesthesiology and Intensive Care, Anadolu Hospital, Zonguldak, Turkey \\ ${ }^{3}$ Department of Anesthesiology and Intensive Care, Medipol University Mega Hospital Complex, Istanbul, Turkey \\ ${ }^{4}$ Department of Biostatistics and Bioenformatics, Düzce University, Faculty of Medicine, Duzce, Turkey
}

İlknur Suidiye Yorulmaz:https://orcid.org/0000-0002-1441-6360

Gökçe Akman Köse: https://orcid.org/0000-0002-0980-3825

Yavuz Demiraran: https://orcid.org/0000-0003-0811-4945

Şengül Cangür: https://orcid.org/ 0000-0002-0732-8952

ÖZ

Amaç: Çalışmamızda lidokain ve lidokain+ ketamine ile intravenöz rejyonel anestezi (IVRA) uygulanan hastalardaki elektrokardiyografik değişiklikleri karşılaştırmayı amaçladık.

Materyal ve Metot: Çalı̧̧mamız prospektif, gözlemsel, randomize ve çift kör olarak yapıldı. IVRA altında kol ve önkol operasyonu geçirecek ASA I -II statüsünde 18-60 yaș arası 70 hasta çalışmaya alındı. Çift kaflı turnike opere edilecek ekstremiteye yerleştirildi. Hastalar randomize ve olarak 2 gruba ayrıldı. Group 1: \% 0,5 Lidokain+Ketamin $0,8 \mathrm{mg} / \mathrm{kg} ; 40 \mathrm{ml}$. Group 2: \% 0,5 Lidokain $40 \mathrm{ml}$ olarak belirlendi. Enjeksiyondan 20 dakika sonra distal kaf şişirilerek proksimal kaf 3 dakikada bir $50 \mathrm{mmHg}$ hızda indirildi. Zaman periyodları turnike indirilmesinin başlamasından itibaren $0,5,10,15,30,45,60$. dakika ve turnike indirilmesinden 10 dakika sonra olarak belirlendi. İnvaziv olmayan kan basıncı değerleri, kalp atım hızı, puls oksimetre değerleri kaydedildi. Elektrokardiyografik kayitlar alınarak PR, RR, QT intervalleri, QTc değerleri kaydedildi.

Bulgular: Lidokain+ketamin grubunda QT basal değerleri QT5. dk, QT10. dk, QT15. dk, QT30. dk, QT45. dk, QT60. dk ve QTtur10 değerlerinden düşük bulundu. QTc bazal değerleri grup lidokain + ketamin QTctur10 değerlerinden daha düşük bulundu $(\mathrm{p}<0,001)$.

Sonuç: Lidokain grubunda belirgin bir değişiklik gözlenmedi. Turnike indirilmesinden sonra lidokain+ketamin grubunda QT, QTc değerlerinde ve özellikle noninvaziv kan basıncı değerlerinde belirgin artıș gözlendi.

Anahtar Kelimeler: Elektrokardiyogram, IVRA, ketamin, lidokain

\section{ABSTRACT \\ Objective: We compared cardiac effects, electrocardiographic changes by intravenous regional anesthesia (IVRA) with lidocaine and lidocaine + ketamine.}

Materials and Methods: Prospective, randomised, double blind study was performed in the operating room of Düzce University Hospital. Seventy patients between 18-60 years, ASA I-II and who were undergo IVRA for arm and forearm operations. Patients were divided into two groups randomly. Group 1: $0.5 \%$ Lidocaine+Ketamine $0.8 \mathrm{mg} / \mathrm{kg} ; 40 \mathrm{ml}$. Group 2: $0.5 \%$ Lidocaine $40 \mathrm{ml} .20$ minutes after injection the distal cuff was inflated, and the proximal cuff deflated with a rate of $50 \mathrm{mmHg}$ in every 3 minutes. Time periods of the recordings were $0,5,10,15,30,45,60$ th minutes after the beginning of deflation and 10 minutes after the deflation. Non-invasive blood pressure values, heart rate, pulse oximetry values were recorded. Electrocardiographic changes on PR, RR intervals, QT, QTc were recorded.

Results: QT basal value measured in Group Lidocaine+Ketamine is significantly lower than QT5th min, QT10th min, QT15th min, QT30th min, QT45th min, QT60th min and QTtur10. QTcbasal values measured in Group Lidocaine+Ketamine were significantly lower than QTc tur10 values $(\mathrm{p}<0.001)$.

Conclusions: In Group Lidocaine, no significant differences was observed. After the deflation of tourniquet was completed, QT and QTc values and noninvasive blood pressures were significantly higher in Group Lidocaine + Ketamine.

Keywords: Electrocardiogram, IVRA, ketamine, lidocaine

\footnotetext{
Sorumlu Yazar / Corresponding Author:

İlknur Suidiye Yorulmaz

Yayın Bilgisi / Article Info:

Gönderi Tarihi/ Received: 24/06/2019

Ph.D., Department of Anesthesiology, Faculty of Medicine, Univer- Kabul Tarihi/ Accepted: 25/12/2019

sity of Düzce, Duzce, Turkey.

Online Yayın Tarihi/ Published: 30/06/2020

Tel: 90 - 3805421390

Fax: 90 - 3805421387

E-mail: issekerdtf@gmail.com

Atıf / Cited: Yorulmaz IS et al. Effect of different anesthetic agents management on electrocardiographic changes of patients operated under regional intravenous anesthesia. Online Türk Sağllk Bilimleri Dergisi 2020;5(2):210-220. doi: 10.26453/otjhs.581681
} 


\section{INTRODUCTION}

Intravenous regional anesthesia (IVRA) is an effective and simple method which can be used by upper or lower extremity operations under 1 hour, IVRA was performed by August Bier in 1908 with procaine. In 1963 it was growing up again when it was performed with lidocaine by Holmes. ${ }^{1}$

It is used especially by forearm and hand surgery. Intravenous regional anesthesia is preferred when compared to general anesthesia, it is safe when applied correctly, it is advantageous from general anesthesia in emergency operations, it has a high chance of success compared to peripheral nerve blocks and it is easier to apply. ${ }^{1,2}$ In this technique, the drug is removed from the tissues by blood after the removal of the tourniquet. Undesirable side effects can be seen as a result of the mixing of local anesthetic into the systemic circulation and these complications are rarely fatal. ${ }^{1,2}$

In IVRA many local anesthetics and adjuvant agents can be used. Effective doses and adverse effect profiles of each drug are different from another. Especially their cardiac autonomic effects must be considered during practice. In a review of Guay it was observed that electrocardiographic (ECG) changes, ventricular tachycardia and cardiac arrest could appear during IVRA with lidocaine $\% 1 .^{3}$

Prolonged QT interval may cause the ventricular arrhythmia and may increases the mortality and morbidity. ${ }^{4}$ Duration of QT interval is heart-rate dependent. Because of this, it is recommended to drive a heart rate corrected (QTc) interval is is most valuable. ${ }^{5}$ QTc interval greater than 440 miliseconds is considered long. ${ }^{6}$ Serious arrhythmias are related with QTc $\geq 600$ miliseconds. $^{7}$

Intravenous lidocaine effects on QT and QTc interval. ${ }^{4}$ Studies regarding the effect of lidocaine on QTc interval during anesthesia are limited. To our knowledge, there is no data about the influence of lidocaine or lidocaine+ketamine on QTc changes induced by intravenous regional anesthesia.

Although the effect of ketamine on QTc interval has not been shown yet, it has been stated that it may trigger torsade de pointes (TdP) type arrhythmias due to its sympathomimetic effect. Ketamine-induced QTe prolongation is shown in animal models. ${ }^{8-9}$ In our study we planned to assess cardiac effects and ECG changes appearing by IVRA with lidocaine and lidocaine+ketamine.

\section{MATERIALS AND METHODS}

After obtaining the approval of the Ethic's committee of Duzce University Noninvasive Researchs (Date:11/10/2013. Reference No:2013/447) and Clinical Trials Registry Platform (Clinical Trials.gov: NCT02063620), informed written consent was obtained from each patient. In randomized, prospective, double-blind trial, 70 patients with age 18-60 years and American Society of Anesthesiologist (ASA) physical status I-II and who are undergoing operation in forearm and hand under 1 hour were included the study.

Exclusion criterias: Allergy to study drugs, serious cardiac, respiratory diseases, renal failure, drug addiction, pregnancy, liver failure, genetic diseases of musculoskeletal system, use of antiepileptic drugs, abnormal thyroid functions, electrolyte imbalance, left ventricular hypertrophy, diabetes mellitus, high serum cholesterol levels, high body mass index, patient with bradicardia, myocardial ischemia and operation period over 1 hour.

Patient were divided into 2 groups randomly. Randomization was performed by blindly receiving an equal number of group 1 and group 2 written papers from a box other than one participant, and determining which method would be applied to the patient. Group 1( $\mathrm{n}=35): 0.5 \%$ Lidocaine+Ketamine $0.8 \mathrm{mg} /$ $\mathrm{kg}, 40 \mathrm{ml}$. Group $2(\mathrm{n}=35): 0.5 \%$ Lidocaine, $40 \mathrm{ml}$. In premedication room two 20 -gauge venous cannula was placed each on operative and non-operative extremities of all patients. All patients were premedicated with midazolam $0.05 \mathrm{mg} / \mathrm{kg}$ intravenously in premedication unit. Ten minutes after premedication 12 channel basal electrocardiograms (ECG) were recorded at supine position.

In operation room 12 lead electrocardiogram, noninvasive blood pressures and pulse oximeter levels were monitored (Datex Ohmeda Monitor, GE Health Care, Finland). Noninvasive systolic, diastolic, mean arterial pressures, heart rate, pulse oximeter $(\mathrm{SpO} 2)$ values, adverse effects were recorded 5 minute intervals throughout the operation and anesthesia. Double cuffed was placed on the extremity to be operated to hinder nerve injuries. Extremity venous blood was purged by Esmarch Bandage, then proximal cuff was inflated with a pressure $100 \mathrm{mmHg}$ higher than systolic blood pressure and the bandage was displaced. Distal tourniquet was inflated to $100 \mathrm{mmHg}$ to prevent tourniquet leakage, while the injection was slowly completed at a rate of $20 \mathrm{ml} / \mathrm{min}(120 \mathrm{sec}-$ onds).

After local anesthetic was injected with a rate of 20 
$\mathrm{ml} / \mathrm{min}$, the intravenous cannula on this extremity was displaced. 20 minutes after injection distal cuff was inflated and proximal cuff was deflated with a rate of $50 \mathrm{mmHg}$ every 5 minutes.

\section{Time intervals:}

Basal: Ten minutes after premedication, TO: Starting the tourniquet deflation,

T5: 5 minute after tourniquet deflation,

T10: 10 minute after tourniquet deflation,

T15: 15 minutes after tourniquet deflation,

T30: 30 minutes after tourniquet deflation,

T45: 45 minutes after tourniquet deflation,

T60: 60 minutes after tourniquet deflation,

Tur 10: 10 minutes after tourniquet complate deflation.

QTc with QT interval adjusted for heart rate was calculated by dividing QT distance (milisecond) by RR interval (milisecond) to square root. (Bazett formula: Corrected QT, QTc $=$ QT Interval $/ \sqrt{ }($ RR interval $) .{ }^{4}$

Power Analysis: A power analysis revealed that a group size of 30 would provide an alpha level = 0.05 and beta level $=0.90$, based on a mean after tourniquet released QTc increase of 58 (SD 16) ms [5] and regarding a QTc increment of $25 \%$ as significant.

Statistical Analysis: Descriptive statistics (mean, standard deviation, median, 1st (percentile 25, Q1) and 3rd (percentile 75, Q3) values, minimum, maximum, percentage) were calculated. The normality assumption for quantitative variables was examined by the Shapiro Wilk test. Independent samples t test and Mann-Whitney U test were used for group comparisons. Repeated Measures ANOVA (post hoc Unequal Tukey HSD test) was used for intergroup comparisons of time-dependent variables. The relationship between qualitative variables was examined by Pearson Chi-Square test. SPSS 22 program was used for statistical evaluations and $\mathrm{p}<0.05$ was considered statistically significant.

\section{RESULTS}

A total of 65 patients were included in the study. Four of them were excluded from the study because of the prolongation of their operation time and pain. Two patients were excluded from the study due to hypertension. The analysis was performed on 59 patients.

The age, body mass index (BMI), weight, gender, operation times and duration of tourniquet were not statistically different between the groups.

Age, gender, BMI and weight were found to be homogenous. There wasn't any significant differences between the groups in operation and tourniquet durations (Table 1).Non invasive systolic arterial pressure (SAP) basal, diastolic arterial pressure (DAP) basal, mean arterial pressure (MAP) basal, heart rate (HR) basal, SpO2 basal, PR interval basal, QT interval basal, QTc basal and RR segment homogeneity of groups was examined. It was found that the groups were homogeneous in terms of other basal variables except for the QTc basal mean value (Table 2).

Mean Arterial Pressure: It was observed that the difference between the groups varied according to the MAP values measured in different periods or the differences between the MAP values were different in both groups $(p<0.001)$. The MAP 5th min, MAP 10th min, MAP 15th min, MAP 30th min, MAP 45th min and MAP 60th min values measured in Group1 were significantly lower than the values measured in group 2, respectively $(\mathrm{p}<0.001, \mathrm{p}<0.001, \mathrm{p}=0.003$, $\mathrm{p}=0.003, \mathrm{p}=0.007, \mathrm{p}=0.003)$. The value of MAP tur 10th measured in Group 1 is significantly higher than the value measured in group $2(p<0.001)$. Also, the value of MAP basal measured in Group 1 is significantly lower than the values measured in other periods(respectively $p=0.004, \quad p=0.010, \quad p=0.002$, $\mathrm{p}=0.001, \mathrm{p}=0.006, \mathrm{p}<0.001, \mathrm{p}<0.001, \mathrm{p}<0.001)$. The MAP basal value measured in Group 2 is significantly lower than the values measured in other periods ( $p<0.001$ for each). Heart Rate (HR):Significant differences were found between the HRvalues measured at different periods in each group. $(p<0.001)$. The value of HRtur10 measured in group 1 is significantly higher than the value measured in group 2 $(p<0.001)$. The HRbasal value measured in group 1 was significantly higher than the values measured in HR15th min $(p=0.040)$, HR30th $\min (p<0.001)$, HR45th min $(p<0.001)$ and HR 60th $\min (p=0.001)$ periods. The HRtur 10 value measured in Group 1 is significantly lower than the value measured in group $2(\mathrm{p}<0.001)$. The measured HRbasal value in group 2 was significantly lower than the value measured in HR 5th min period, while it was significantly higher than the values measured in other periods $(p<0.001$ for each).

PR segment (PR) measurements: It was observed that the difference between the groups did not change according to the PR values measured at different periods or the differences between the PR values were similar in both groups $(\mathrm{p}=0.342)$.

QT interval (QT): The difference between the QT values measured at different periods was found to be different in the groups $(\mathrm{p}=0.006)$. ( $\underline{\text { Table } 3})$

QTc interval: QTcbasal values measured in Group 1 
were significantly lower than QTc tur10 values ( $p$ $<0.001)$. In Group 2 no significant difference was observed (Table 4).

RR interval: It was observed that the differences between the groups varied according to the RR values measured in different periods or the differences between the RR values were different in both groups $(p<0.001)$. This difference was caused by the measured value in the RRtur 10 period. The RRtur10 value measured in Group 1 was significantly lower than the value measured in group $2(\mathrm{p}<0.001)$ (Table 5).

Adverse events:

Side effects were examined in 2 groups as the ones during the tourniquet and those after the tourniquet.

During the tourniquet: Group lidocaine + ketamine did not show any side effects in 24 patients. In lidocaine + ketamine group discoloration of the skin was occured in five patients distally of tourniquet. In one patient tourniquet pain was observed. There was no side effect was observed 22 patients in lidocaine group. Four patients had a discoloration in the distal part of the tourniquet and 2 patients had tourniquet pain.

After the tourniquet release: In the lidocaine + ketamine group, 29 patients had hallucinations and disorientation, and 1 patient had dizziness and tremor. There was no pain in the first 10 minutes after the tourniquet was opened. In the lidocaine group, 29 patients had pain in the operation area after the tourniquet was opened. No hallucinations and disorientation observed after the tourniquet was opened in the lidocaine group.

\section{DISCUSSION AND CONCLUSION}

IVRA can be performed with many local anesthetics and adjuvant agents. ${ }^{1}$ In our study we planned to compare cardiac effects and ECG changes by IVRA with lidocaine and lidocaine plus ketamine. Our primary outcome: Is ketamine+lidocaine combination makes any differences on QT and QTc versus sole lidocaine solution? We found that there were significant differences for QT and QTc measurements in lidocaine +ketamine group. We observed that QT basal measurement was significantly lower than 10th, 30th and 60th minute measurements. In lidocaine group there wasn't significant difference between measurement periods for QT measurements. We observed same results for QTc interval.

The secondary outcome: Is Ketamine+ lidocaine solution attenuates the arrythmia incidence? The side effects seen in the literature in IVRA are mostly related to the cardiovascular system and central nerv- ous system. Our aim in our study was to assess whether these potential cardiac effects were potentiated by addition of adjuvant agents.

Various local anesthetics and adjuvant agents can be used in IVRA. Their effective dose and side effect profiles are different ${ }^{1}$ and their effects on autonomic cardiac functions should be considered during the application. The selection of the local anesthetic agent, the dose to be administered and the adjuvant agent, the tourniquet used is important in the success of IVRA. Rosenberg et al. commented that the tourniquet, which could not be kept under enough pressure, could cause the local anesthetic agent to pass into the systemic circulation and cause adverse events and toxic reactions. Generally, tourniquet pressure should be $100-150 \mathrm{mmHg}$ high or $250-300$ $\mathrm{mmHg}$ from systolic arterial pressure to prevent tourniquet leakage. ${ }^{11-13}$

The most preferred local anesthetic agents in IVRA are prilocaine and lidocaine. ${ }^{14,15}$ Lidocaine $0.25 \%$ to $0.5 \%$ solutions are preferred at a dose of $3 \mathrm{mg} / \mathrm{kg}$. ${ }^{16}$ In the study of A study on anesthetized sheep, the electrocardiographic and hemodynamic effects of intravenous infusion of bupivacaine, ropivacaine, levobupivacaine and lidocaine were compared. ${ }^{17}$ In this study, it was observed that iv infusion of high dose bupivacaine resulted in more significant changes in RR, PR, QRS, QT, QTc intervals. Ropivacaine caused less ECG changes than levobupivacaine. Lidocaine was associated with very low changes. $^{18}$

The main site of action of local anesthetic agents on the cardiovascular system is the voltage-dependent sodium channels in the myocardium. They reduce electrical stimulation, conduction velocity, and myocardial contraction in the myocardium. They lead to prolongation of the delivery rate in a dose dependent manner during the PR interval and QRS duration. This leads to depression in spontaneous pacemaker activity. Persistent sodium channel blockade predisposes to re-entran arrhythmias. ${ }^{18}$ They cause hypotension with arteriolar dilatation. Lidocaine blocks sodium channels in 'fast-in-fast-out'. ${ }^{19}$

Cardiovascular effects of local anesthetics occur at higher systemic concentrations than central nervous system effects. One of the missing aspects in our study is that blood lidocaine levels are not examined. The second pitfall is that the QTc basal values in the lidocaine + ketamine group were found to be statistically higher. This may be due to the high mean arterial pressure of the patients in the ketamine group. In the group lidocaine + ketamine, an increase of the 
heart rate 10 minutes after the tourniquet completely opened was observed ( $p<0.001)$. In the lidocaine group, heart rate was decreased in other periods compared to basal values. There was no change in the PR values between the groups. $(p=0.342)$. The QT interval was longer in the lidocaine + ketamine group. At the same time, QT interval was found to be prolonged according to basal values in this group. QTc values were also higher in lidocaine + ketamine group. The QTc value was found to be highest in the lidocaine + ketamine group at the 10th minute after the tourniquet was completely opened. ( $p<0.001)$. No significant difference was observed in the lidocaine group. The RR segment was shortened in both groups. However, 10 minutes after the tourniquet was opened, it was observed that RR levels were lower in ketamine + lidocaine group compared to baseline $(p<0.001)$. We believe this is due to the increase in heart rate of ketamine. Ketamine in the literature; It is recommended to use $0.5-1 \mathrm{mg} / \mathrm{kg}$ intravenous, $0.25 \mathrm{mg} / \mathrm{kg}$ epidural anesthesia and $0.5-1 \mathrm{mg} / \mathrm{kg}$ caudal anesthesia. ${ }^{20-22}$

In our study, $0.5 \%$ lidocaine, $40 \mathrm{ml}$ dose and $0.8 \mathrm{mg}$ ketamine were used as adjuvant agents because of the short duration of the systemic side effects and the short duration of the effect of local anesthetics.

Various agents and methods have been used to accelerate the onset of anesthesia in IVRA that reduce the dose of local anesthetics, alleviate tourniquet pain, and prolong postoperative analgesia. Nonsteroidal antiinflammatory drugs such as opioids, paracetamol, ketorolac, and tenoxicam, alphamimetic agents such as clonidine and dexmedetomidine, muscle relaxants such as baclofen, intravenous anesthetics such as ketamine, anticholin esterases such as neostigmine and adjuvant agents such as magnesium are used in IVRA. $^{23-26}$

Ketamine is used as an adjuvant to increase efficacy in IVRA. In our study, it was clinically observed that the tolerability of tourniquet pain was better in the ketamine group. ${ }^{27}$

Seizures reported at doses $1.4 \mathrm{mg} / \mathrm{kg}$ and cardiac arrest with doses as low as $2.5 \mathrm{mg} / \mathrm{kg}$. Cardiac arrests and deaths were reported with lidocaine and bupivacaine only. The lowest dose associated with a cardiac arrest was $2.5 \mathrm{mg} / \mathrm{kg}$ for lidocaine and $1.6 \mathrm{mg} / \mathrm{kg}$ for bupivacaine. ${ }^{3}$ The blood level at which Lidocaineassociated seizures begin is 10-12 microg / $\mathrm{mL}$. When the blood level of lidocaine is increased, significant respiratory depression occurs, the cardiotoxic effects of higher levels (20-25 microg / $\mathrm{mL}$ ) become
apparent.In our study there wasn't developed any seizure and respiratuary depression. But in lidocaine+ ketamine group hallusination and desorientation developed frequently after the tourniquet was opened. In lidocaine group pain becomeappearentin $10 \mathrm{~min}$ utes after tourniquet opened.In the literature, there are clinical studies on epidural, interscalene blocks and QT and QTc prolongations during spinal anesthesia. However, no study has been found concerning IVRA and ECG changes.

Local anesthetics and sedative hypnotised agents including ketamine prolong the QTc interval. Arythmia incidence is higher with long QTc interval.

When ketamine is used as an adjuvant agent with lidocaine, QTc interval is much longer than lidocaine alone from basal levels. Systemic effect of lidocain is less with IVRA ketamine increased the QTc intervals used as adjuvant agent ketamine for lidocain during the IVRA. After the deflation of tourniquet was completed, in ketamine group QT and QTc values especially NIBP (Non invasive blood pressure) were significantly higher and it was observed that arrythmia risk was increased (Figure 1).

The incidence of adverse effects increases due to the risk of consistence of a complicated structure throughout multiple drug combinations. So, drug combinations must be used carefully by patients who are especially under risks.

This research did not receive any specific grant from funding agencies in the public, commercial, or notfor-profit sectors.

Ethics Committee Approval: Our study was approved by the Duzce University Noninvasive Researchs Ethics Committee (Date: 11/10/2013, decision no: 2013/447).

Conflict of Interest: No conflict of interest was declared by the authors.

Author Contributions: Concept - ISY; Supervision ISY; Materials - GAK, ISY; Data Collection and/or Processing - GAK, ISY; Analysis and/ or Interpretation - SC, ISY, YDN; Writing -, ISY.

Peer-review: Externally peer-reviewed.

\section{REFERENCES}

1. Barry LA, Balliana SA, Galeppi AC. Intravenous regional anesthesia (Bier Block). Tecniques in Regional Anesthesia and Pain Management. 2006;10:123-131.

2. Henderson CL, Warriner CB, McEwen JA, Merrick PM. A North American survey of intra- 
venous regional anesthesia. Anaesth Analg. 1997;85(63):858.

3. Guay J. Adverse events associated with intravenous regional anesthesia (Bier block) a systematic review: Journal of Clinical Anesthesia. 2009;21 (8):585-594.

4. Owczuk R, Wujtewicz MA, Sawicka W, Piankowski A, Polak-Krzeminska A, Morzuch E, et al. The effect of intravenous lidocaine on QT changes during tracheal intubation. Anesthesia. 2008;63(9):924-31.

5. Shah RR. The significance of QT interval in drug development. Br J Clin Pharmacol. 2002;54 (2):188-202.

6. Owczuk R, Sawicka W, Wujitewcz MA, Kawecka A, Lasec J, Wujitewcz M. Influence of spinal anesthesia on corrected QT interval. Reg Anesth Pain Med. 2005;30(6):548-52.

7. Khan IA. Clinical and therapeutic aspects of congenital and acquired long QT syndrome. Am J Med. 2002;112(1):58-66.

8. Wisely NA, Shipton EA. Long QT syndrome and anesthesia. Eur J Anaesthesiol. 2001;19:853-9.

9. Hamlin RL, Kijtawornrat A, Keene BW, Hamlin DM. QT and RR intervals in conscious and anesthetized guinea pigs with highly varying RR intervals and given QTc-lengthening test articles. Toxicological Sciences. 2003;76(2):437-442.

10. Booker PD, Whyte SD, Ladusans EJ. Long QT syndrome and anaesthesia. British Journal of Anaesthesia 2003; 90: 349-66.

11. Rosenberg PH. 1992 ASRA lecture. Intravenous regional anesthesia: nerve block by mu anesthesia? Saudi J Anaesth. 2010;4(2):55-62.

12.1JP Sharma, R Salhotra. Tourniquets in orthopedic surgery. Indian J Orthop. 2012;46(4): 377383.

13. Tetzlaff JE, Yoon HJ, Walsh M. Regional Anaesthetic technique and the incidence of tourniquet pain. Can J Anaesthesia. 1993;40(7):591.

14. Abdulla WY, Fadhil NM. A new approach to intravenous regional anesthesia. Anesth Analg. 1992;75(4):597-601.

15. Choyce A, Peng P. A systematic review of adjuncts for intravenous regional anesthesia for surgical procedures. Can J Anaesth. 2002;49(1):3245.

16. Barry LA, Balliana SA, Galeppi AC. Intravenous Regional Anesthesia (Bier Block): Tecniques in Regional Anesthesia and Pain Management. 2006;10:123-131.

17. Guinet P, Estebe JP, Ratajczak-Enselme M, Bansard JY, Chevanne F, Bec D, Lecorre P, Wodey
E, Ecoffey C. Electrocardiographic and hemodynamic effects of intravenous infusion of bupivacaine, ropivacaine, levobupivacaine, and lidocaine in anesthetized ewes. Reg Anesth Pain Med. 2009;34(1):17-23.

18. Gristwood RW, Greaves JL. Levobupivacaine: a new safer long acting local anaesthetic agent. Expert Opin Investig Drugs. 1999;8(6):861-76.

19. Clarkson CW, Hondeghem LM. Mechanism for bupivacaine depression of cardiac conduction. Fast block of sodium channels during the action potential with slow recovery from block during diastole. Anesthesiology 1985;62(4):396-405.

20. Passariello M, Almenrader N, Canneti A, Rubeo L, Haiberger R, Pietropaoli P. Caudal analgesia in children: $\mathrm{S}(+)$-ketamine vs $\mathrm{S}(+)$-ketamine plus clonidine. Pediatric Anesthesia. 2004;14:851855.

21. Himmelseher S, Ziegler-Pithamitsis D, Argiriadou H, Martin J, Jelen-Esselborn S, Kochs E. Small dose $\mathrm{S}(+)$ ketamine reduces postoperative pain when applied with ropivacaine in epidural anesthesia for total knee arthroplasty. Anesth Analg. 2001;92(5):1290-1295.

22. Almenrader N, Passariello M, D'Amico G, Haiberger R, Pietropaoli P. Caudal additives for postoperative pain management in children: $\mathrm{S}(+)$ ketamine and neostigmine. Paediatr Anaesth. 2005; $15: 143$.

23. Acalovschi I, Cristea T. Intravenous regional anesthesia with meperidine. Anesth\&Analg. 1995;81(3):539.

24. Bigat Z, Boztuğ N. RIVA'da lidokain ve lidokaine eklenen tenoksikam ve deksametazonun karşılaştırılması. Türk Anest Rean Der. 2004;32:200.

25. Kleinschmidt S, Stockl W, Wilhelm W, Larsen R. The addition of clonidine to prilocaine for intraveneous regional anaesthesia. Eur J Anaesthesiol. 1997;14(1):40.

26. Turan A, Memis D, Karamanlıglu B, Güler T, Pamukçu Z. Intravenous regional anesthesia using lidocaine and magnesium. Anesth Analg. 2005;100:1189.

27. Kumar A, MD DNB (Anaes), Sharma DK, B. Addition of ketamine or dexmedetomidine to lignocaine in intravenous regional anesthesia: A randomized controlled study. J Anaesthesiol Clin Pharmacol. 28(4): 501-504. 
Table 1.Demographic datas of the study population. Values are represented as mean \pm standart deviation.

\begin{tabular}{|l|l|l|l|l|l|}
\hline & \multicolumn{2}{|l|}{$\begin{array}{l}\text { Grouplidocaine+ } \\
\text { ketamine (n=30) }\end{array}$} & \multicolumn{2}{|l|}{ Grouplidocaine (n=29) } & P values \\
\hline Age (year) & $38 \pm 13$ & $39 \pm 13$ & 0.933 \\
\hline Weight (kilogram) & $80 \pm 11$ & $76 \pm 17$ & 0.181 \\
\hline Body massindex & $27.7 \pm 4.7$ & $27.1 \pm 6.1$ & 0.859 \\
\hline \multirow{2}{*}{ Gender } & Male & Female & Male & Female & 0.887 \\
\cline { 2 - 5 } & $\begin{array}{l}53.3 \% \\
(\mathrm{n}=16)\end{array}$ & $\begin{array}{l}46.7 \% \\
(\mathrm{n}=14)\end{array}$ & $\begin{array}{l}55.2 \% \\
(\mathrm{n}=16)\end{array}$ & $\begin{array}{l}44.8 \% \\
(\mathrm{n}=13)\end{array}$ & \\
\cline { 1 - 4 } Operation time (minute) & $46.87 \pm 11.98$ & $41.90 \pm 15.96$ & 0.349 \\
\hline Tourniquet time (minute) & $58.83 \pm 11.37$ & $57.83 \pm 15.79$ & 0.897 \\
\hline
\end{tabular}


Table 2. Mean arterial pressure, heart rate, PRbasal, QTbasal, QTcbasal,and RRbasal measurements of the patients. Values are represented as mean \pm standart deviation.

\begin{tabular}{|c|c|c|c|c|}
\hline & Group & $\mathbf{n}$ & Mean \pm SD & $p$ \\
\hline \multirow{2}{*}{$\begin{array}{l}\text { Mean arterial pressure } \\
(\mathrm{mmHg})\end{array}$} & $\begin{array}{l}\text { Lidocaine+ } \\
\text { ketamin }\end{array}$ & 30 & $88 \pm 11$ & \multirow[t]{2}{*}{0.307} \\
\hline & Lidocaine & 29 & $92 \pm 13$ & \\
\hline \multirow{2}{*}{$\begin{array}{l}\text { Heart rate } \\
\text { (Beat } / \mathrm{min})\end{array}$} & $\begin{array}{c}\text { Lidocaine+ }^{\text {ketamin }}\end{array}$ & 30 & $75 \pm 12$ & \multirow{2}{*}{0.313} \\
\hline & Lidocaine & 29 & $71 \pm 12$ & \\
\hline \multirow{2}{*}{$\begin{array}{l}\text { PR segment basal } \\
\text { (msec) }\end{array}$} & $\begin{array}{l}\text { Lidocaine+ } \\
\text { ketamin }\end{array}$ & 30 & $168 \pm 25$ & \multirow[t]{2}{*}{0.780} \\
\hline & Lidocaine & 29 & $169 \pm 20$ & \\
\hline \multirow[t]{2}{*}{ QTbasal (msec) } & $\begin{array}{c}\text { Lidocaine+ } \\
\text { ketamin }\end{array}$ & 30 & $389 \pm 38$ & \multirow[t]{2}{*}{0.195} \\
\hline & Lidocaine & 29 & $377 \pm 35$ & \\
\hline \multirow{2}{*}{$\begin{array}{l}\text { QTcbasal } \\
\text { (msec) }\end{array}$} & $\begin{array}{c}\text { Lidocaine+ }^{\text {ketamin }}\end{array}$ & 30 & $437 \pm 42$ & \multirow[t]{2}{*}{$0.007 *$} \\
\hline & Lidocaine & 29 & $410 \pm 33$ & \\
\hline \multirow{2}{*}{ RRbasal } & $\begin{array}{c}\text { Lidocaine+ } \\
\text { ketamin }\end{array}$ & 30 & $803 \pm 127$ & \multirow[t]{2}{*}{0.144} \\
\hline & Lidocaine & 29 & $864 \pm 156$ & \\
\hline
\end{tabular}

*There isn't any difference basal values between groups except of QTc basal levels. 
Table 3. Comparison of QT measurements between groups. Values are represented as mean \pm standart deviation.

\begin{tabular}{|l|c|c|c|c|c|}
\hline & $\begin{array}{c}\text { Lidocaine+ } \\
\text { ketamine } \\
\mathbf{( n = 3 0 )} \\
\text { (milisecond) }\end{array}$ & $\begin{array}{c}\text { P values } \\
\text { (Comparison basal } \\
\text { levels with other } \\
\text { periods in groups) } \\
\text { Lidocaine+ } \\
\text { ketamine }\end{array}$ & $\begin{array}{c}\text { Lidocaine } \\
\text { (n=29) } \\
\text { (milisecond) }\end{array}$ & $\begin{array}{c}\text { P values } \\
\text { (Comparison } \\
\text { of time } \\
\text { periods } \\
\text { between two } \\
\text { groups })\end{array}$ & $\begin{array}{c}\text { P values } \\
\text { (Comparison } \\
\text { basal levels with } \\
\text { other periods) in } \\
\text { group } \\
\text { Lidocaine }\end{array}$ \\
\hline QT basal & $389.20 \pm 38.21$ & & $376.69 \pm 34.86$ & $\mathbf{0 . 0 1 8 *}$ & \\
\hline QT 0 minute & $399.20 \pm 40.81$ & $\mathrm{p}=0.013$ & $376.69 \pm 31.75$ & $\mathbf{0 . 0 3 1 ^ { * }}$ & $>0.05$ \\
\hline QT5th minute & $399.33 \pm 46.08$ & $\mathrm{p}=0.012 \&$ & $374.62 \pm 32.06$ & $>0.05$ & $>0.05$ \\
\hline QT10th minute & $405.47 \pm 47.17$ & $\mathrm{p}<0.001 \&$ & $378.62 \pm 30.41$ & $\mathbf{0 . 0 1 1 ^ { * }}$ & $>0.05$ \\
\hline QT15th minute & $402.53 \pm 47.31$ & $\mathrm{p}<0.001 \&$ & $380.83 \pm 33.80$ & $\mathbf{0 . 0 3 8 ^ { * }}$ & $>0.05$ \\
\hline QT30th minute & $402.00 \pm 46.03$ & $\mathrm{p}<0.001 \&$ & $384.68 \pm 28.55$ & $>0.05$ & $>0.05$ \\
\hline QT45th minute & $402.13 \pm 48.85$ & $\mathrm{p}=0.002 \&$ & $383.17 \pm 34.37$ & $>0.05$ & $>0.05$ \\
\hline QT60th minute & $407.33 \pm 43.06$ & $\mathrm{p}=0.001 \&$ & $381.52 \pm 30.83$ & $\mathbf{0 . 0 1 3 *}$ & $>0.05$ \\
\hline QTtur10 minute & $387.73 \pm 48.97$ & $\mathrm{p}<0.001 \&$ & $381.24 \pm 32.66$ & $>0.05$ & \\
\hline
\end{tabular}

*There is a significant differance between groups statistically in QT measurements in time periods. \& QT basal value measured in Group lidocaine+ketamine is significantly lower than QT5th min, QT10th min, QT15th min, QT30th min, QT45th min, QT60th min and QTtur10. 
Table 4. QTc measurements of the groups. Values are represented as mean \pm standart deviation.

\begin{tabular}{|l|l|l|l|}
\hline & $\begin{array}{c}\text { Lidocaine+ketamine } \\
(\mathbf{n}=\mathbf{3 5}) \\
(\mathbf{m i l i s e c o n d})\end{array}$ & $\begin{array}{c}\text { Lidocaine (n=35) } \\
(\mathbf{m i l i s e c o n d )}\end{array}$ & P values \\
\hline QTcbasal & $436.90 \pm 41.55$ & $409.76 \pm 32.77$ & 0.017 \\
\hline QTc 0 minute & $440.47 \pm 44.28$ & $403.66 \pm 27.66$ & 0.001 \\
\hline QTc 5th minute & $440.87 \pm 53.81$ & $407.93 \pm 31.24$ & 0.004 \\
\hline QTc 10th minute & $440.10 \pm 58.45$ & $410.79 \pm 30.80$ & 0.010 \\
\hline QTc 15th minute & $439.03 \pm 53.15$ & $403.62 \pm 34.34$ & 0.002 \\
\hline QTc 30th minute & $429.13 \pm 52.58$ & $407.31 \pm 25.99$ & 0.049 \\
\hline QTc 45th minute & $436.87 \pm 52.88$ & $402.00 \pm 33.21$ & 0.002 \\
\hline QTc 60th minute & $438.67 \pm 52.86$ & $404.69 \pm 28.78$ & 0.003 \\
\hline QTc tur10 minute & $461.53 \pm 55.31 *$ & $405.97 \pm 31.67$ & $<0.001$ \\
\hline \multirow{2}{*}{${ }^{2}$ QTcbasal values measured in Group 1 were significantly lower than QTc tur10 values $(p<0.001)}$.
\end{tabular}


Table 5. Presents that RR levels of the patients. value is lower than basal values in group. Values are presented as mean \pm standart deviation.

\begin{tabular}{|l|c|c|c|c|}
\hline & $\begin{array}{c}\text { Lidocaine+ketamine } \\
\text { (n=30) } \\
\text { (milisecond) }\end{array}$ & $\boldsymbol{P}$ values & $\begin{array}{c}\text { Lidocaine (n=29) } \\
\text { (milisecond) }\end{array}$ & $\boldsymbol{P}$ values \\
\hline RR basal & $802.93 \pm 126.80$ & & $857.66 \pm 155.61$ & \\
\hline RR 0 minute & $833.20 \pm 147.67$ & $>0.05$ & $879.31 \pm 139.76$ & $>0.05$ \\
\hline RR 5th minute & $836.67 \pm 159.98$ & $0.039^{*}$ & $852.14 \pm 135.87$ & $>0.05$ \\
\hline RR 10th minute & $867.73 \pm 170.45$ & $<0.001^{*}$ & $856.28 \pm 119.82$ & $>0.05$ \\
\hline RR 15th minute & $856.27 \pm 168.36$ & $0.001^{*}$ & $901.24 \pm 148.57$ & $0.009^{*}$ \\
\hline RR 30th minute & $898.93 \pm 191.34$ & $<0.001^{*}$ & $898.90 \pm 127.96$ & $0.013^{*}$ \\
\hline RR 45th minute & $862.53 \pm 167.19$ & $0.001^{*}$ & $917.66 \pm 139.29$ & $<0.001^{*}$ \\
\hline RR 60th minute & $877.73 \pm 154.31$ & $<0.001^{*}$ & $896.28 \pm 130.82$ & $0.002^{*}$ \\
\hline RR tur10 minute & $714.13 \pm 116.34$ & $<0.001^{*}$ & $890.21 \pm 130.05$ & $0.049^{*}$ \\
\hline
\end{tabular}

